\title{
Creation of a New Advising Metric to Develop Viable Individual Senior Projects
}

Prof. Charles Pringle, Central Washington University

Charles Pringle is a professor in the Mechanical Engineering Technology program at Central Washington University. Charles teaches upper division courses including the senior capstone course.

\section{Dr. Craig Johnson P.E., Central Washington University}

Dr. Johnson is the coordinator of the MET Program at Central Washington University. He is also the Foundry Educational Foundation Key Professor and coordinates the Cast Metals Program. This will be is second year as the Chair of the Pacific Northwest Section. 
Creation of a New Advising Metric to Develop Viable Individual Senior Projects

\author{
Charles O. Pringle, EIT \\ Dr. Craig Johnson, P.E. \\ Central Washington University
}




\section{Abstract:}

Determining whether an individual senior project is a 'good' project can be a difficult task. To aid the professor in associated advising, but more importantly, the student, a rubric was developed that helps indicate whether a student is proposing an acceptable senior project.

The scope of this effort includes the creation of an assessment tool that measures critical aspects of a good senior project. This includes quantifying the following 'engineering merit' aspects: problem statement, function statement, requirements, analyses, performance predictions, and evaluation. These 'aspects' exist in all of the capstone projects, regardless of the subject matter or discipline.

Students refer to their proposals when using the metric. Professors review and advise in a timely manner. Students can better determine if they have proposed an 'acceptable' senior project before the professor agrees to final acceptance.

The students and professors have applied the rubric to projects in a Mechanical Engineering Technology (MET) senior capstone course. The results showed deficiencies in some projects. This forced changes in the parameters of the project to make it an acceptable project. Assessment of the pedagogical impact of this metric was determined via surveys and comparisons of relevant course data over a number of years.

\section{Introduction:}

Senior Project is a process that every engineering student must negotiate. For universities that do not have an active research program for seniors to participate in, defining an individual senior project that will succeed can be difficult. The purpose of this paper is to present an assessment tool that will aid the student, as well as the professor, in proposing a good senior project.

Senior Project for the MET Program at Central Washington University starts in the fall and progresses through all three quarters of the academic year. Fall quarter is devoted to developing the student's engineering proposal. Their proposal includes an introduction to the engineering problem, design and analysis, methods and construction, testing method, budget/schedule/project management, discussion, and conclusion. The aim of the proposal is to convince 'management' that this is a viable engineering project. This is a lot of information for a student to develop in a 10 week period. Therefore, it is imperative that they determine their engineering problem as soon as possible.

Students tend towards projects that are too large, too complicated, and very time consuming. Two of the outcomes for this course directly conflict with the student's sense of an engineering problem: ABET $3 \mathrm{i}^{1}$ (respect for diversity, diverse input, societal and global issues) and ABET 3k (commitment to quality, timeliness, and continuous improvement). It is always a challenge attempting to guide the students towards a realistic project. Many students want to design a system. Systems are 'Death Stars' to the student's success. They are too large, too time consuming, and often require resources that are not readily available. So how to get them to scale back?

In the past a Requirements, Analysis, Design, Drawings (RADD) ${ }^{2}$ approach was used (ABET 3k). Assessment by RADD was used to improve the performance of the student. This assessment 
worked well, but it did not aid the student, or professor, in addressing the engineering problem and getting to a complete solution. Something was needed to address the beginning of the process (ABET 3i). We chose to focus on the engineering problem, function statement, and augmenting RADD with evaluation methods.

The attempt of the proposed rubric is to have the students spend some time at the beginning of the process assessing what they are doing. This should hopefully "open” their eyes to the real scope of their 'Death Star' project and convince them to scale back. If the student understood the scope of work need to complete their 'Death Star' project, maybe they would recognize the desirability of scaling back to something that was attainable.

\section{Method:}

The purpose of the assessment tool is to provide feedback to the students by having them rate their project proposal. Do they have a proper function statement? Do their requirements have quantitative values in them? A survey was developed that attempted to provide the students with some of these answers.

The development of the survey centered on helping the students identify the crucial elements of their paper (Problem, Function, Requirements, and Evaluation). First and foremost is having a proper engineering problem. If the students do not develop a proper problem, all other aspects of the proposal become much more difficult. Much like a Free Body Diagram (FBD), if the FBD is incorrect, a correct solution will never be attained. If the students can develop a correct function statement and have requirements that have quantitative values, the rest of their proposal can plausibly be developed from this base.

Many students approach Senior Project as 'a technical endeavor,' instead of what it really is solving an engineering problem. An engineering project starts with a problem that can be addressed using engineering. Our capstone courses document and evaluate this engineering design process. A technical endeavor or device excludes those attributes and is inappropriate for our needs. Often, just having students think in those terms immediately eliminates a lot of their ideas or suggestions. The survey attempts to have them think in this manner. The survey asks the students what is their engineering problem? What are you trying to solve? The students then rate how they think they are doing in each category (see Appendix A). The next couple of questions deal with function statements and requirements. This is used primarily by the faculty member to aid the student in properly defining the problem the student is attempting to solve. In addition to poor problem definitions, many students litter their function statements with specifications/requirements.

A student provided the following function statement: "To dump material out of a trailer bed by using a small cylinder contented [sic] to a scissor device that lays flat when not in use and able to extends up.” The student reviewed the survey and felt that they had indeed provided a correct function statement. When this was reviewed by the professor, the professor refuted the student's assertion of correctness. The professor also provided feedback as to why this was not a correct function statement. The student was then able to provide the following: "To tilt six foot platform to a $40^{\circ}$ with a load of 500lb.” The student is still including requirements, but it is an improved 
function statement. The final function statement is "To tilt a six foot platform.” The $40^{\circ}$ and load of 500lb were moved to the requirements.

The following were evaluated when looking at student's proposal: poorly defined problem, creating a technical device, building a system, and testing issues. A poorly defined project, at the beginning, was a solar HVAC unit. A student wanted to build the system for the University of Washington Environmental Innovation challenge. Two problems, it is starting out as a project and it is a system. The student was instructed to recruit a couple of team members. Second was determining the individual engineering problems within the system for each student. There were several issues that made defining the engineering problem for this proposal difficult. Wanting to work with ammonia quickly became an issue of expense and safety. The heat exchanger is more a matter of specification than design engineering. Eventually, the engineering problems became the heating coil (Energy provided by the sun), the evaporative chiller, and the fan coil unit.

Wanting to create a technical device is a common problem. A student, interested in aviation, wanted to build an R/C model that was a Vertical Take Off and Landing (VTOL) aircraft. Great project, but how do you accomplish the measurement of, "The transition from vertical to horizontal flight modes will be more stable and smoothly...” with limited resources. Without question there is plenty of engineering in this technical device, it's just that it will be difficult for the student to complete all that is required to produce this 'Death Star' project. An air worthy air frame has to be designed around two different propulsion systems (An engineering project alone). The student could propose a design and build it, but without the predicted engineering result - it's just a technical device. Another student wanted to build a bike rack for an apartment. There are many bike racks on the market. How to define or create an engineering problem associated with a 'bike rack?' We can focus on requirement, manufacturing, loads, functionality, etc. For manufacturing the requirement could be the unassembled unit fit in a shipping box of 165 inches of length and girth combined with length less than 108 inches. Weight and assembly with hand tools commonly found in the home could be additional constraints to force this out of the technical device realm.

The HVAC and a gear box proposal fall into the system category. These were managed by creating teams and dissecting the project into a defined area that each student is responsible for. The interesting part is creating dividing lines that if one student fails to perform, the other students can still complete a project.

The issue of testing often modifies or changes a project. There are many reasons for this. The university does not have the facilities to perform the requisite tests. The student cannot afford the test. Or, it would be time consuming and difficult to determine the results. A student was considering a wood chip feeder for a commercial smoking operation. The customer wanted to automate the process of feeding wood chips into the smoker, they also wanted the most amount of smoke/chip of wood, efficient transfer of heat to the wood chip, and the removal of the ash. This engineering problem would involve energy balance and efficiencies, transfer of heat, transfer of mass, conversions of energy. A multi discipline approach (thermodynamics, chemistry, heat transfer, structural components, and electro-mechanical components) would be 
required to solve this engineering problem. Testing the above becomes a project unto itself. This is much more than a single student can handle in 30 weeks of work.

Each week feedback is provided to the students. As the quarter progresses, the focus shifts down through the survey questions. The responses on the survey did not affect the students score on the survey. They received full credit for completing the survey.

Results:

The RADD results in Table 1 shows data for the past 10 years. From Fall of 2004 to Fall of 2014 the results show an improvement demonstrating that as an assessment tool, RADD is working.

Table 1. RADD Results.

\begin{tabular}{|l|c|l|c|c|c|c|c|}
\hline YEAR & $\begin{array}{l}\text { Require } \\
\text {-ments } \\
\text { 3i (Ave) }\end{array}$ & $\begin{array}{l}\text { Stdev 3i } \\
\text { Sample } \\
\text { Size }\end{array}$ & $\begin{array}{l}\text { Analysis } \\
\text { 3k (Ave) }\end{array}$ & $\begin{array}{l}\text { Stdev 3k } \\
\text { Sample } \\
\text { Size }\end{array}$ & $\begin{array}{l}\text { Design } \\
\text { 3d (Ave) }\end{array}$ & $\begin{array}{l}\text { Drawing } \\
\text { 3g (Ave) }\end{array}$ & $\begin{array}{l}\text { Sample } \\
\text { Size }\end{array}$ \\
\hline 2004-5, Fall & 60.0 & & 67.0 & & 51.0 & 39.0 & 13 \\
\hline 2005-6, Fall & 73.0 & & 69.0 & & 83.0 & 77.0 & 13 \\
\hline 2006-7, Fall & 75.0 & & 74.0 & & 72.0 & 71.0 & 24 \\
\hline 2007-8, Fall & 71.0 & & 54.0 & & 72.0 & 79.0 & 16 \\
\hline 2008-9, Fall & 83.0 & & 86.0 & & 84.0 & 85.0 & 11 \\
\hline 2009-10 Fall & 81.2 & & 70.6 & & 80.6 & 83.5 & 16 \\
\hline 2010-11 Fall & 80.9 & & 83.6 & & 89.1 & 80.0 & 11 \\
\hline 2011-12 Fall & 83.8 & 24.3 & 46.4 & 15.9 & 81.1 & 18.6 & 14 \\
\hline 2012-13 Fall & 82.6 & 19.6 & 55.2 & 20.4 & 43.0 & 42.6 & 22 \\
\hline 2013-14 Fall & 84.5 & 33.0 & 74.1 & 39.2 & 75.9 & 82.8 & 30 \\
\hline
\end{tabular}

Appendix A lays out the survey questions. The Required Element column lists the items to be assessed. Some additional information under Beneficial Elements was also included. The Questions column gives the questions that the students responded to. The Metric Description lists the choices the students could use to respond to the questions. The Researcher Response Metric column information was used by the professor to review the student proposal. Appendix B shows the results of the student survey. Each numbered row corresponds to a student and his or her responses. The column headings $(\mathrm{C}$ through $\mathrm{W})$ are the questions. The individual student responses are below the headings. The professor's review of the same student proposal with the professor's assessment can be found in Appendix C.

\section{Discussion:}

Because of the survey, the RADD data scores for ABET 3i improved. The results in Table 1 indicate a $2.3 \%$ increase in the ABET 3 i score (So far the highest recorded). This is the first year 
the survey was implemented. Since the increase is within the standard deviation, the increase may not be attributed to the survey.

The survey questions were excellent in forcing the students to think about their project in the correct engineering terms. The questions provided a tool for the professor to refer to when asking the student questions concerning their proposal. As seen in the survey results (see Appendix B \& C), the student's self-assessment differs from the professor assessment. It seems the professor sees the potential of the engineering merit in the project before the student does. The problem statement responses coincide more closely. The largest discrepancy begins at the function statement. The professor often refers the students to their textbook ${ }^{3}$ for the definition and example of function statements. The requirements column is another place that the professor often did not agree with the students. These points of disagreement are where students need the most guidance and assistance.

This current assessment process requires a lot of interaction on a lot of different proposals. This is necessary to properly guide the student to a good proposal. Providing meaningful feedback to the students in a timely manner is difficult at times and this may have had an effect on the data. As can be seen by Table 1, the class size has grown significantly in the last two years. Since faculty resources have not been increased commensurately, this unfortunately means that the time spent with each individual student has been greatly reduced.

\section{Conclusion:}

This survey was created to support improvement of outcomes ABET 3i and 3k as applied to our senior capstone course for a Mechanical Engineering Technology program. The results in Table 1 indicate a $2.3 \%$ increase in the ABET 3 i score. The students and faculty reviewed the survey questions providing the students with feedback on their progress towards a good senior project. This process was considered a success and future work will continue to refine the process.

\section{References:}

1. ABET, http://www.abet.org/ 2015.

2. Oncina, C., Johnson, C. (2005). “Use of MET Capstone Course RADDical Metric.” 2005 Annual ASEE

Conference.

3. Mott, R. L., (5 ${ }^{\text {th }}$ Ed.). (2014). Machine Elements in Mechanical Design. Boston, MA: Pearson.

Appendix A: Survey Questions 


\begin{tabular}{|c|c|c|c|}
\hline Required Elements & Questions & $\begin{array}{l}\text { Metric } \\
\text { Description }\end{array}$ & $\begin{array}{l}\text { Researcher Response } \\
\text { Metric }\end{array}$ \\
\hline \multirow[t]{3}{*}{ Engineering Merit } & \multirow{3}{*}{$\begin{array}{l}\text { Does your proposal } \\
\text { have engineering } \\
\text { merit that can be } \\
\text { exemplified through } \\
\text { the use of } \\
\text { Requirements, } \\
\text { Analysis, Design } \\
\text { Parameters, and } \\
\text { Documentation } \\
\text { (RADD)? Is your } \\
\text { engineering merit... }\end{array}$} & Poor & $\begin{array}{l}\text { This project could be easily } \\
\text { "spec'd." The opportunity } \\
\text { for RADD would be } \\
\text { difficult to obtain. }\end{array}$ \\
\hline & & Good & $\begin{array}{l}\text { There is opportunity for } \\
\text { RADD, but it may require } \\
\text { additional requirements to } \\
\text { produce the RADD } \\
\text { opportunities. }\end{array}$ \\
\hline & & Excellent & This project has RADD. \\
\hline \multirow[t]{3}{*}{ Problem statement } & \multirow[t]{3}{*}{$\begin{array}{l}\text { Does your proposal } \\
\text { have a problem } \\
\text { statement? Is your } \\
\text { problem statement... }\end{array}$} & Poor & $\begin{array}{l}\text { There is no engineering } \\
\text { problem, it is hard to } \\
\text { deduce the engineering } \\
\text { problem, or this appears to } \\
\text { be more of a spec'd } \\
\text { problem }\end{array}$ \\
\hline & & Good & $\begin{array}{l}\text { There is an engineering } \\
\text { problem, but it may need to } \\
\text { be refined or changed in } \\
\text { scope. }\end{array}$ \\
\hline & & Excellent & $\begin{array}{l}\text { There is a an engineering } \\
\text { problem }\end{array}$ \\
\hline \multirow[t]{3}{*}{ Function statement } & \multirow[t]{3}{*}{$\begin{array}{l}\text { Does your function } \\
\text { statement tell what } \\
\text { the device must do? }\end{array}$} & Disagree & $\begin{array}{l}\text { There is no apparent } \\
\text { functions statement. The } \\
\text { student has written } \\
\text { something, but it is not a } \\
\text { proper function statement. }\end{array}$ \\
\hline & & $\begin{array}{l}\text { Neither agree or } \\
\text { disagree }\end{array}$ & $\begin{array}{l}\text { There is a function } \\
\text { statement, but it may not } \\
\text { be complete or it includes } \\
\text { requirements }\end{array}$ \\
\hline & & Agree & $\begin{array}{l}\text { A proper function } \\
\text { statement: What must the } \\
\text { device do? }\end{array}$ \\
\hline \multirow[t]{3}{*}{ Requirements } & \multirow{3}{*}{$\begin{array}{l}\text { Does your proposal } \\
\text { include quantitative } \\
\text { requirements that } \\
\text { your device must } \\
\text { meet? }\end{array}$} & Disagree & $\begin{array}{l}<=15 \% \text { of the } \\
\text { requirements have numbers }\end{array}$ \\
\hline & & $\begin{array}{l}\text { Neither agree or } \\
\text { disagree }\end{array}$ & $\begin{array}{l}15.1-84.9 \% \text { of the } \\
\text { requirements have numbers }\end{array}$ \\
\hline & & Agree & $\begin{array}{l}>=85 \% \text { of the } \\
\text { requirements have numbers }\end{array}$ \\
\hline Requirements & & 2 or less & 2 or less \\
\hline
\end{tabular}




\begin{tabular}{|c|c|c|c|}
\hline \multirow[t]{3}{*}{ Required Elements } & Questions & $\begin{array}{l}\text { Metric } \\
\text { Description }\end{array}$ & $\begin{array}{l}\text { Researcher Response } \\
\text { Metric }\end{array}$ \\
\hline & \multirow{2}{*}{$\begin{array}{l}\text { How many } \\
\text { significant } \\
\text { requirements does } \\
\text { your proposal } \\
\text { include? }\end{array}$} & 3 to 5 statements & 3 to 5 requirements \\
\hline & & 6 or greater & 6 or greater \\
\hline \multirow[t]{3}{*}{ Analysis } & \multirow{3}{*}{$\begin{array}{l}\text { Does your proposal } \\
\text { include analyses that } \\
\text { determine parameters } \\
\text { of your device? }\end{array}$} & Disagree & $\begin{array}{l}<15 \% \text { of the analysis } \\
\text { determines parameters of } \\
\text { the device }\end{array}$ \\
\hline & & $\begin{array}{l}\text { Neither agree or } \\
\text { disagree }\end{array}$ & $\begin{array}{l}15.1-84.9 \% \text { of the } \\
\text { analysis determines } \\
\text { parameters of the device, }\end{array}$ \\
\hline & & Agree & $\begin{array}{l}85 \% \text { of the analysis } \\
\text { determine parameters of } \\
\text { the device. }\end{array}$ \\
\hline \multirow{3}{*}{$\begin{array}{l}\text { Performance } \\
\text { predictions }\end{array}$} & \multirow{3}{*}{$\begin{array}{l}\text { Does your proposal } \\
\text { include quantitative } \\
\text { predictions of } \\
\text { performance by your } \\
\text { device? }\end{array}$} & Disagree & Disagree \\
\hline & & $\begin{array}{l}\text { Neither agree or } \\
\text { disagree }\end{array}$ & Neither agree or disagree \\
\hline & & Agree & Agree \\
\hline \multirow{3}{*}{$\begin{array}{l}\text { Performance } \\
\text { predictions }\end{array}$} & \multirow{3}{*}{$\begin{array}{l}\text { How many } \\
\text { quantitative } \\
\text { predictions of } \\
\text { performance does } \\
\text { your proposal } \\
\text { include? }\end{array}$} & 2 or less & 2 or less \\
\hline & & 3 to 5 statements & 3 to 5 statements \\
\hline & & 6 or greater & 6 or greater \\
\hline \multirow[t]{3}{*}{ Evaluation methods } & \multirow{3}{*}{$\begin{array}{l}\text { How many evaluation } \\
\text { methods do you } \\
\text { describe in your } \\
\text { proposal? }\end{array}$} & 2 or less & 2 or less \\
\hline & & 3 to 5 statements & 3 to 5 statements \\
\hline & & 6 or greater & 6 or greater \\
\hline \multirow[t]{2}{*}{ Evaluation methods } & \multirow{2}{*}{$\begin{array}{l}\text { Include descriptions } \\
\text { of resources needed } \\
\text { to evaluate your } \\
\text { device. }\end{array}$} & No & \\
\hline & & Yes & \\
\hline \multirow[t]{3}{*}{ Scope } & \multirow{3}{*}{$\begin{array}{l}\text { The scope that is } \\
\text { written in your } \\
\text { proposal; is the } \\
\text { engineering merit... }\end{array}$} & Poor & Scope is a spec'd project. \\
\hline & & Good & $\begin{array}{l}\text { The engineering merit is } \\
\text { too small or easy. }\end{array}$ \\
\hline & & Excellent & There is engineering merit. \\
\hline \multirow[t]{3}{*}{ Cost } & \multirow{3}{*}{$\begin{array}{l}\text { What is the estimated } \\
\text { cost of your project? }\end{array}$} & less than $\$ 500$ & \\
\hline & & $\$ 500$ to $\$ 1000$ & \\
\hline & & $\begin{array}{l}\text { greater than } \\
\$ 1000\end{array}$ & \\
\hline Size & $\begin{array}{l}\text { What is the estimated } \\
\text { size of your project? }\end{array}$ & $\begin{array}{l}\text { fit in a school } \\
\text { locker }\end{array}$ & \\
\hline
\end{tabular}




\begin{tabular}{|c|c|c|c|}
\hline Required Elements & Questions & $\begin{array}{l}\text { Metric } \\
\text { Description }\end{array}$ & $\begin{array}{l}\text { Researcher Response } \\
\text { Metric }\end{array}$ \\
\hline & & $\begin{array}{l}\text { fit in a school } \\
\text { classroom }\end{array}$ & \\
\hline & & $\begin{array}{l}\text { larger than a } \\
\text { classroom }\end{array}$ & \\
\hline \multirow[t]{3}{*}{$\begin{array}{l}\text { Individual } \\
\text { Commitment }\end{array}$} & \multirow{3}{*}{$\begin{array}{l}\text { What is your } \\
\text { individual } \\
\text { commitment to the } \\
\text { project? }\end{array}$} & little & $\begin{array}{l}\text { See if word count can be } \\
\text { used to evaluate their level } \\
\text { of effort. }\end{array}$ \\
\hline & & some & \\
\hline & & complete & \\
\hline \multirow{2}{*}{$\begin{array}{l}\text { Individual } \\
\text { Commitment }\end{array}$} & \multirow{2}{*}{$\begin{array}{l}\text { Include a narrative } \\
\text { reflecting your } \\
\text { commitment to this } \\
\text { project. }\end{array}$} & & \\
\hline & & & \\
\hline \multicolumn{4}{|l|}{ Beneficial Elements } \\
\hline \multirow[t]{2}{*}{ External interaction } & \multirow{2}{*}{$\begin{array}{l}\text { Will this project have } \\
\text { any external } \\
\text { interaction (Outside } \\
\text { CWU)? }\end{array}$} & no & no \\
\hline & & yes & yes \\
\hline \multirow[t]{2}{*}{ External interaction } & \multirow{2}{*}{$\begin{array}{l}\text { If your project does } \\
\text { include external } \\
\text { interaction, please } \\
\text { include information } \\
\text { regarding the external } \\
\text { support tor } \\
\text { interaction, otherwise } \\
\text { leave blank. }\end{array}$} & & \\
\hline & & & \\
\hline \multirow[t]{2}{*}{ Commercial Aspects } & \multirow{2}{*}{$\begin{array}{l}\text { Will this project have } \\
\text { any commercial } \\
\text { aspects? }\end{array}$} & no & no \\
\hline & & yes & yes \\
\hline \multirow[t]{2}{*}{ Commercial Aspects } & \multirow{2}{*}{$\begin{array}{l}\text { If your project does } \\
\text { include commercial } \\
\text { aspects, please } \\
\text { include information } \\
\text { regarding the } \\
\text { commercial aspect, } \\
\text { otherwise leave } \\
\text { blank. }\end{array}$} & & \\
\hline & & & \\
\hline \multirow[t]{2}{*}{ Publishable } & \multirow{2}{*}{$\begin{array}{l}\text { Will this project be } \\
\text { published or do you } \\
\text { intend it to be } \\
\text { published? }\end{array}$} & no & no \\
\hline & & yes & yes \\
\hline
\end{tabular}




\begin{tabular}{|l|l|l|l|}
\hline Required Elements & Questions & $\begin{array}{l}\text { Metric } \\
\text { Description }\end{array}$ & $\begin{array}{l}\text { Researcher Response } \\
\text { Metric }\end{array}$ \\
\hline Publishable & $\begin{array}{l}\text { If your project will be } \\
\text { published, please } \\
\text { include information } \\
\text { regarding your } \\
\text { intention to publish } \\
\text { or disseminate your } \\
\text { project, otherwise } \\
\text { leave blank. }\end{array}$ & & \\
\hline
\end{tabular}




\section{APPENDIX B: Survey Results}

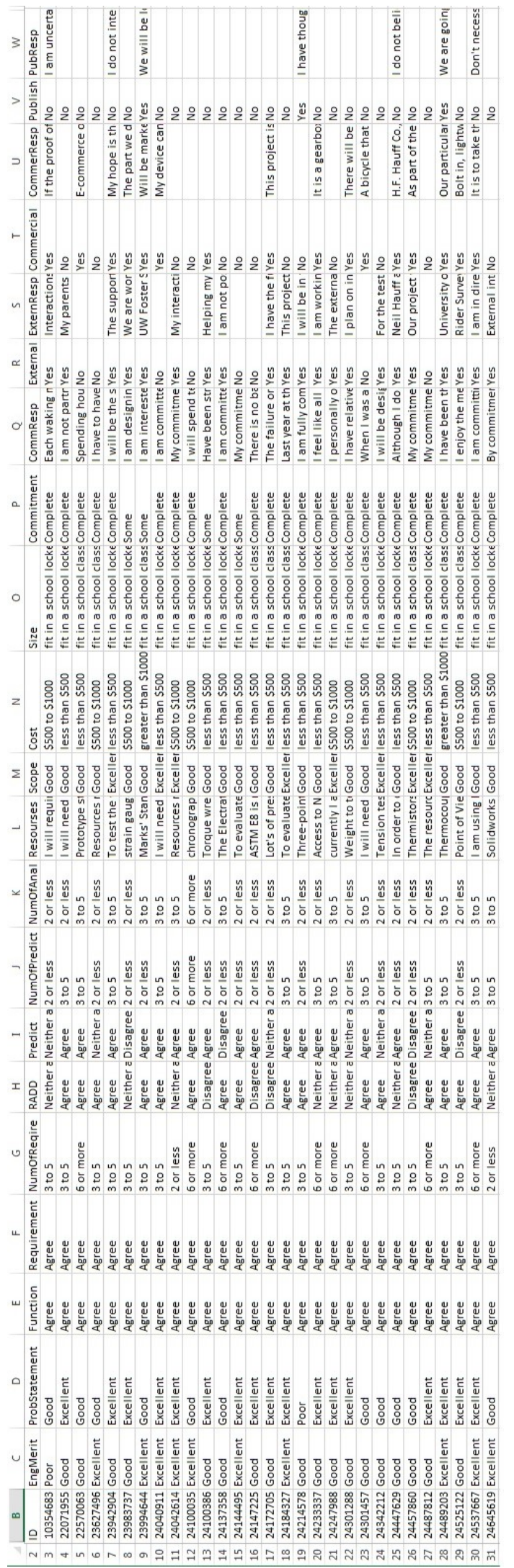

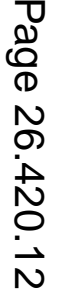




\section{Appendix C. Researcher Assessment of student survey questions}

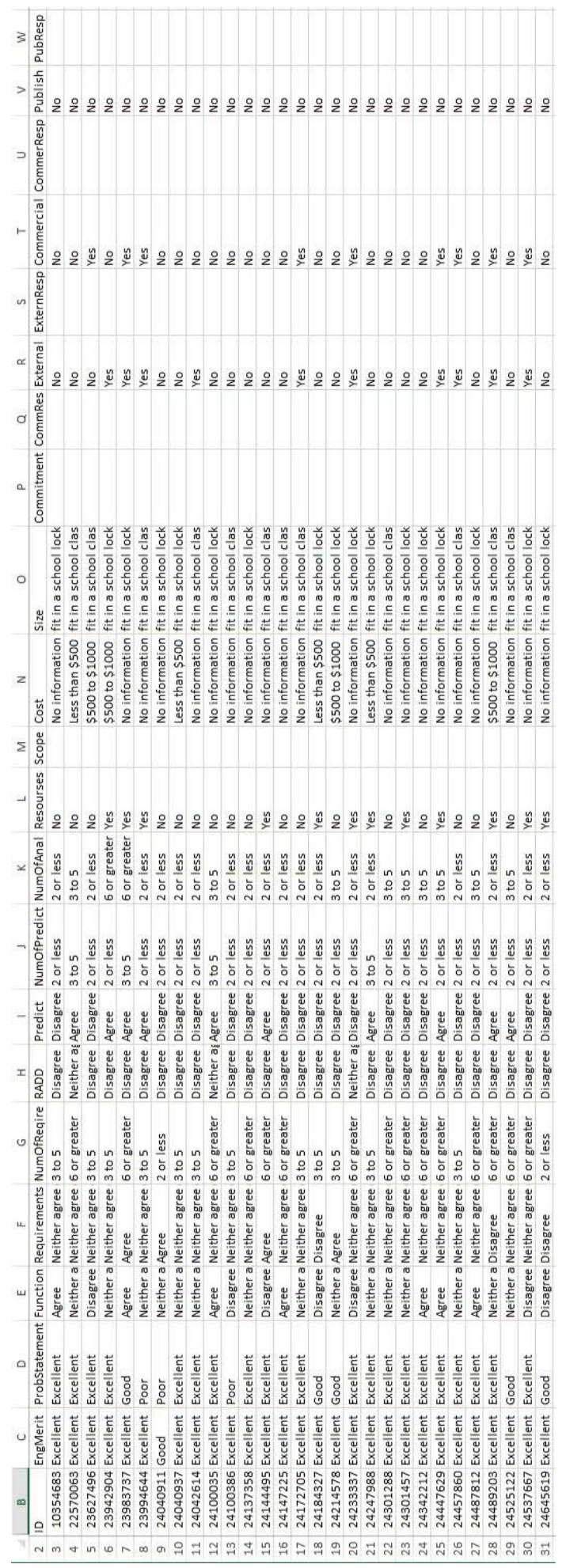

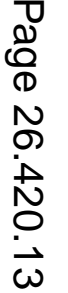

